\title{
Privatization Impact on Economic Growth in Ethiopia: ARDL Approach
}

\author{
Dr. Venkata Krishna Reddy Chinnapareddy ${ }^{1} \quad$ Ashenafi Desalegne Teshome ${ }^{2} \quad$ Dr. Shahid Saheb ${ }^{1}$ \\ 1.Assistant Professor, Department of Public Financial Management and Accounting,CFMD, Ethiopian Civil \\ Service University, Addis Ababa, Post Box No.5648, Ethiopia \\ 2.Senior Finance, Cost, Payment and Receivable Supervisor, Ethiopian Trading Businesses Corporation, Fruits \\ \& Vegetables Trade Business Unit, Addis Ababa, Ethiopia
}

\begin{abstract}
The objective of this paper is as to check whether privatization has long run or short run significant impact on economic growth of Ethiopia by considering real GDP growth as a proxy for economic growth and privatization proceeds as to the measure of the magnitude of privatization. A time series data starting form 1994/95S1 up to 2016/17S2 using some explanatory and response variables. Autoregressive Distributed Lag (ARDL) method to characterize long run and the short run relationship between real GDP growth and independent variables was used. The empirical results reveal that both privatization and foreign direct investment due to privatization are found to have a positive impact on economic growth and statically significant at $1 \& 5$ percent respectively in the long run as well as in the short run. While, inflation and government consumption proxy to corruption affects economic growth negatively in the long run. The unexpected result of private domestic investment had a negative sing and insignificant in the long run. This study has an important policy implication. The findings of this study imply that economic growth can be improved significantly when the privatization police accompanied with other structural change was implemented. Hence policy makers and /or the government should strive to strengthen privatization policies together with other policies. In addition to this effort, there should be a close monitoring and consistent government consumption and budget monitoring strategies, which is used to avoid misallocation and mismanagement of consumption.
\end{abstract}

Keywords: Ethiopia, Privatization, Economic Growth, Co-integration. ARDL

DOI: $10.7176 / J P I D / 48-03$

\section{Introduction}

Economic growth is a sustained increase in the real gross domestic product over a long period of time. Another quantification of economic growth is that national output should be composed of goods and services which satisfy the maximum want of the maximum number of people. Economic growth can be determined by Human resources, National Resources, capital formation and technological development. (Ogbonna and Ebimobowei, 2012). This economic factor can be influenced by privatization because the privatization system adopted by any country can be encouraged or discourage the inflow of foreign direct investment and private domestic investment.

The shift from a socialist-oriented centrally planned economy to a market-oriented mixed economy approach has immersed in privatization as a mechanism of structural adjustment reform program. Privatization, in its narrow sense, is defined as the transfer of public enterprise to the private sector, while in a broad concept; it stands for policies to reduce the role of the state while assigning a larger role for the private sector by allowing market-based economic decisions. The aim of privatization is directed at promoting efficiency and productivity and enhancing sustained growth and at the same ensuring the autonomy and accountability of management.

Despite the fact that privatization, has become a worldwide phenomenon the empirical process, performance and its effect on the countries' economy have shown disparities among countries. Experience has shown that privatization has not been as effective in developing countries as it has been in the developed western countries where infrastructural facilities for privatization were in abundance. The success of privatization by and large depends on the type of strategies employed, which in turn depends on the social, political and economic conditions of the country in question. This has dictated the use of prudent privatization strategies that fit well with the situation on the ground and which may greatly vary from one country to another. The fact that privatization outcomes are not uniform has created a great concern for African countries that are often compelled to implement privatization in an undeveloped economic environment, void of privatization preconditions. According to Debebe (2000), despite their pervasive involvement, African countries have made little effort to evaluate the program and make necessary adjustments especially in the areas of devising appropriate strategies to the extent of looking for feasible alternative economic growth models short of privatization be it in the short or in the long run.

The monopoly which is not favorable for Ethiopian economy and externality problems caused by privately invested firm exists rather than improving the economy. The government should stand, stand, above all, with the real interest of the socio-economic benefits than earnings proceeds from the sale of SOEs, Privatization for the sake of privatizing does not helpful unless it brings socio-economic change in the society with regard to 
investment.

As a result of the differences in the validity of privatization in promoting economic growth, it is still an issue of high debate among many researchers, developed countries governments. IMF, WB who advocate privatization as a good policy for economic growth and developing nation's governments and policymakers who do not accept its validity in promoting economic growth.

Currently According to 2016/17 MoPE annual report of the Privatization and Public Enterprises which has a mandate, taking all necessary measures to publicize the privatization program and its implementation, and the government eased its financial burden and the amount could be used to meet some sorely needed social and economic problems.

\section{Statement of the Problem}

Privatization of state-owned enterprises (SOEs) is treated as an engine of economic growth and development starting from February 1994 since the government released the Ethiopian Privatization Agency Establishment Proclamation. Ethiopia is currently on the way to set for a middle-income economy. Since the privatization process starts in Ethiopia and government overseeing the entities towards improving their performance following privatization. There are inconsistencies in empirical results related to the impact of privatization on economic growth change due to the intervention of privatization in Ethiopia; there are always significant controversies between for and against whether privatized firms improve investment (foreign direct investment and/or private domestic investment) or not in Ethiopia.

Privatization can play a crucial role in the growth performance of the country, as can be evident from its contribution to the different sectors of the economy. During the past twenty-three years, for instance, privatization proceeds have contributed on average about 0.21476 percent to GDP. In addition, it generates the much needed foreign exchange earning that is essentially used to finance the imports of the country. Together with foreign direct investment and export due to privatization, the country uses the foreign exchange generated from the privatization proceeds to import almost all of its intermediate inputs, fuel, and capital goods, which are believed to be essential for the economic growth of the country.

The Transitional Government of Ethiopia (TGE) who came to power in 1991/92 launched a new economic policy where the role of privatization in economic growth was given due importance in the development strategy of the country. However, the privatization supply response to the policy change is not as anticipated. The incentives provided by the new policy to promote privatization could not totally eliminate the anti-privatizationbias incentive structure that originated from the heavy protection of the SOEs for the purpose of retaining special sector of the government such as basic goods of mass consumption producer's enterprises, energy activities, and communication service sectors. As a result, the privatization supply response was weak. The factors behind the sluggish performance of the sector could be due to a combination of the structural problems existing in the whole economy or the insufficiency of policy measures taken to totally nullify the anti-privatization bias that prevailed during the previous years. Therefore, a closer look at the privatization policies followed by the current Government of Ethiopia, in examining the contribution of other structural changes due to privatization and assessing the contribution of privatization to economic growth are issues that will be examined in this study.

In this respect, there is an important question asked whether transferred of SOEs to private ownership in Ethiopia are more likely operating on towards improving the level of technology and management skill and private domestic investment following privatization and does really the privatization program in Ethiopia helps them improving their performance to produce more goods and service that have an effect on economic growth?

To the extent of the knowledge of the researcher, no attempt has been made to study the impact of privatization on the economic benefit and as well their proceeds exert pressure on the level of investment changes.

In the light of this, the paper aims to address to tests the foreign investment \& domestic investment changes following privatization, and also indicates that privatization has a real impact on the economic growth of Ethiopia.

To this end, the following research tests of hypotheses are employed.

\section{Objectives}

The overall objective of this study is to assess the short run and long run impact of privatization on Ethiopian economic growth and to give necessary recommendations and try to answer the following specific objectives.

1. To check there is long run co-integration between economic growth and privatization.

2. To examine foreign direct investment due to privatization has long run or short run effect on economic growth.

3. To assess private domestic investment due to privatization has long run or short run effect on economic growth. 


\section{Hypothesis}

1. Ho: there is no long run co-integration between privatization and economic growth.

Ha: there is long run co-integration between privatization and economic growth

2. Ho: Foreign Direct investment due to privatization has no long run or short run effect on economic growth. Ha: Foreign Direct investment due to privatization has long run or short run effect on economic growth.

3. Ho: Private Domestic Investment due to privatization has no long run or short run effect on economic growth.

Ha: Private Domestic Investment due to privatization has long run or short run effect on economic growth.

\section{The Model, Method of estimation and Data description}

\subsection{The Model}

The model that I am using is broadly similar to Javad et al. (2011). This study uses exogenous economic growth model of Barro (1991) to estimate the relationship between dependent and independent variables. All used variables in this study separate into two controlling and fundamental variables Therefore, based on this theoretical framework developed by Javad et al. (2011) the following empirically estimated level - log linear type of model (with some modification to accommodate other additional variables) is specified.

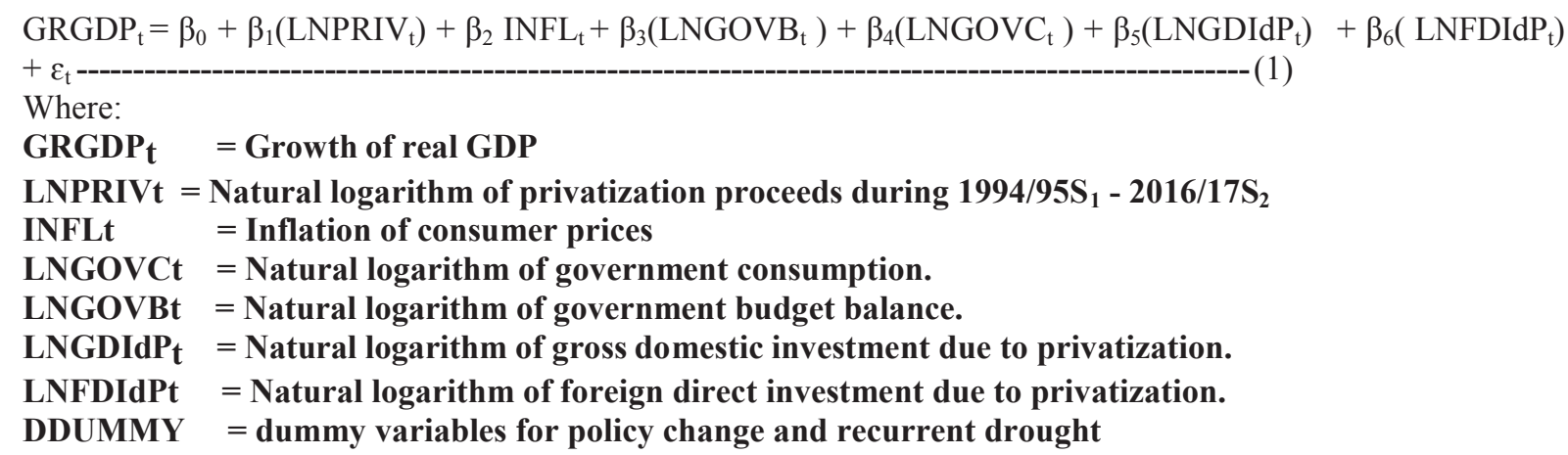

\subsection{Method of analysis}

In this study, the Autoregressive Distributed Lag (ARDL) approach to co-integration, which is proposed by Pesaran and Shin (1997, 1999) and Pesaran, Shin, and Smith (2001) is used to test the long-run co-integration relationships between variables. Because,this approach has a lot of advantages over the Johansen maximum Likelihood (1988) co-integration method. Therefore, the following ARDL model is specified.

$$
\begin{aligned}
& \Delta \text { GRGDP }_{\mathrm{t}}=\beta_{0}+\alpha_{1}\left(\mathrm{GRGDP}_{\mathrm{t}-1}\right)+\alpha_{2}\left(\mathrm{LNPRIV}_{\mathrm{t}-1}\right)+\alpha_{3}\left(\text { INFL }_{\mathrm{t}-1}\right)+\alpha_{4}\left(\mathrm{LNGOVC}_{\mathrm{t}-1}\right) \\
& +\alpha_{5}\left(\text { LNGOVB }_{\mathrm{t}-1}\right)+\alpha_{6}\left(\text { LNGDIdP }_{\mathrm{t}-1}\right)+\alpha_{7}\left(\text { LNFDIdP }_{\mathrm{t}-1}\right) \\
& +\sum_{1=0}^{\mathrm{q} 1} \beta_{11}\left(\Delta \text { GRGDP }_{\mathrm{t}-1}\right)+\sum_{\mathrm{i}=0}^{\mathrm{q} 2} \beta_{21}\left(\Delta \mathrm{LNPRIV}_{\mathrm{t}-1}\right)+\sum_{\mathrm{i}=0}^{\mathrm{q} 3} \beta_{31}\left(\Delta \mathrm{INFL}_{\mathrm{t}-1}\right) \\
& +\sum_{1=0}^{\mathrm{q} 4} \beta_{41}\left(\Delta \text { LNGOVC }_{\mathrm{t}-1}\right)+\sum_{1=0}^{\mathrm{q} 5} \beta_{51}\left(\Delta \text { LNGOVB }_{\mathrm{t}-1}\right)+\sum_{\mathrm{i}=0}^{\mathrm{q} 6} \beta_{61}\left(\Delta \text { LNGDIdP }_{\mathrm{t}-1}\right) \\
& +\sum_{1=0}^{\mathrm{q} 7} \beta_{71}\left(\Delta \text { LNFDIdP }_{\mathrm{t}-1}\right)+\beta_{8} \text { DDUMMY }+\varepsilon_{\mathrm{t}}-(\mathbf{4})
\end{aligned}
$$

Where;

$\mathrm{q}_{1}-\mathrm{q}_{7}=$ are the optimal lag lengths of each variable

$\Delta=$ is the first difference operator

$\beta_{0}=$ is intercept

$\beta_{1}-\beta_{8}=$ are short run coefficients

$\alpha_{1}-\alpha_{7}=$ are long run coefficients of the model

$\varepsilon_{\mathrm{t}}=$ is a white-noise disturbance term used in the model

The estimation of the equation tests for the existence of a long-run relationship among the variables by conducting an F-test or Wald test for the joint significance of the coefficients of the lagged levels of the variables, i.e

$\mathrm{H}_{0}: \alpha_{1}=\alpha_{2}=\alpha_{3}=\alpha_{4}=\alpha_{5}=\alpha_{6}=\alpha_{7}=0$ (No co-integration between variables)

$\mathrm{H}_{1}: \alpha_{1} \neq \alpha_{2} \neq \alpha_{3} \neq \alpha_{4} \neq \alpha_{5} \neq \alpha_{6} \neq \alpha_{7} \neq 0 \quad$ (existence of co-integration between variables)

To test whether there is a long run equilibrium relationship between the variables; bounds test for co- 
integration is carried out as proposed by Pesaran and Shin $(1997,1999)$ and Pesaran, Shin, and Smith (2001). After confirming the existence of long-run relationship among the variables, the following stable long-run model of ARDL; (q1,q2,q3,q4,q5,q6,q7) is estimated:

$$
\begin{aligned}
\operatorname{GRGDP}_{t}=\gamma_{0} & +\sum_{i=0}^{q 1} \gamma_{11}\left(\text { LNPRIV }_{t-1}\right)+\sum_{i=0}^{q 2} \gamma_{21}\left(\text { INFL }_{t-1}\right)+\sum_{i=0}^{q 3} \gamma_{31}\left(\text { LNGOVC }_{t-1}\right) \\
& +\sum_{i=0}^{q 4} \gamma_{41}\left(\text { LNGOVB }_{t-1}\right)+\sum_{i=0}^{q 5} \gamma_{51}\left(L N G D I d P_{t-1}\right)+\sum_{i=0}^{q 6} \gamma_{61}\left(\text { LNFDIdP }_{t-1}\right) \\
& ------------(5)
\end{aligned}
$$

The next step is to estimate the vector error correction model that indicates the short run dynamic parameters (adjustment parameters that measure the speed of correction to long-run equilibrium after a short-run disturbance). The standard ECM is estimated as follows:

$$
\begin{aligned}
\Delta G R G D P_{t}=\alpha_{0} & +\sum_{i=0}^{q 1} \alpha_{11}\left(\Delta G R G D P_{t-1}\right)+\sum_{i=0}^{q 2} \alpha_{21}\left(\Delta L N P R I V_{t-1}\right)+\sum_{i=0}^{q 3} \alpha_{31}\left(\Delta I N F L_{t-1}\right) \\
& +\sum_{i=0}^{q 4} \alpha_{41}\left(\Delta L N G O V C_{t-1}\right)+\sum_{i=0}^{q 5} \alpha_{51}\left(\Delta L N G O V B_{t-1}\right) \\
& +\sum_{i=0}^{q 6} \alpha_{61}\left(\Delta L N G D I d P_{t-1}\right)+\sum_{i=0}^{q 7} \alpha_{71}\left(\Delta L N F D I d P_{t-1}\right) \\
& +\alpha_{8} D D U M M Y+\delta E_{t-1}+E_{t}-------(6)
\end{aligned}
$$

Where, all variables are as defined before,

$\alpha_{0}$ is the intercept and $\alpha_{1}-\alpha_{7}$ refers to the short run coefficients.

$\mathrm{E}_{\mathrm{t}}=$ represents the error term and

$\delta=$ is the speed of adjustment parameter to long-run equilibrium, i.e the percentage semiannual correction of a deviation from the long run equilibrium the semiannual before.

ddummy $=$ are dummy variable for recurrent drought

$\mathrm{ECM}_{\mathrm{t}-1}=$ is the first leg of the error correction term.

After estimating the long run and short run model, misspecification test, normality test, serial correlation test, heteroscedasticity test and cumulative sum of recursive residuals (CUSUM) and the cumulative sum of squares of recursive residuals (CUSUMSQ) test for stability of the model is undertaken to check the robustness of the model. In order to estimate the models and to perform the pre-estimation and post-estimation diagnostic tests, Eviews 9.5 statistical packages are used.

\subsection{Data Sources and description}

Necessary semiannual secondary data on GRGDPt, GOVCt, GOVBt \& INFLt was collected from the National Bank of Ethiopian website, Ministry of finance and economic cooperation (MoFEC), World Development Indicator (WDI) \& United Nations Conference for Trade and Development (UNCTAD). The main sources of secondary data on PRIVt, FDIdPt \& GDIdPt in this study are the Ministry of public enterprise (MoPE), Ethiopian Investment Commission (EIC) \& various publications of International Monetary Fund (IMF) and World Bank (WB). The frequency of dataset is semi-annual and covers the time period of $1994 / 95 \mathrm{~S}_{1}-2016 / 17 \mathrm{~S}_{2}$. All data used in the estimation are in real terms at constant 2010 price and manipulated for use in terms of levels or growth rates in empirical analysis.

\section{Definition of Variable}

In this study, all variables are defined as follows:

Economic growth is an increase in the number of goods and services produced by an economy. It is the percentage rate of increase in real gross domestic product (GDP). As a result, the real gross domestic product (RGDP), which is the gross domestic product deflated by GDP deflator, was used as a proxy for economic growth.

Y = Growth Rate Real Gross Domestic Product (GRGDP): Data are in constant 2010 U.S. dollars GDP at purchaser's prices is the sum of gross value added by all resident producers in the economy plus any product taxes and minus any subsidies not included in the value of the products.

LNPRIVt: Privatization proceeds during 1994/95S $\mathbf{S}_{1}-\mathbf{2 0 1 6} / \mathbf{1 7 S}_{2}$ : Following the methodology used in previous studies, namely Plane (1997), Cook and Uchida (2003), and Bennett (2004), the magnitude of privatization is measured as total privatization proceeds during the period $1994 / 95 \mathrm{~S}_{1}-2016 / 17 \mathrm{~S}_{2}$ as a percentage of GDP. The main reason that the privatization variable is dependent on a period of 23 years (46 Semiannual) is due to the fact 
that all the benefits of privatization on economic growth are not necessarily instantaneous. In other words, the effects of privatization in a particular country for a given year will depend on the overall level of privatization that has taken place in recent history. Furthermore, LNPRIV variable should also capture the relative level of commitment to privatization as an economic policy. If privatization levels were only taken for one specific year, particularly high privatization proceeds for a specific country, in a given year would indicate strong implementation of privatization when, in fact, that particular country could have possibly had no privatization program in previous years.

INFLt: Inflation of consumer prices: is defined as the general rise in the price level of goods and services in an economy over a period of time. It can be classified as food, non-food and general inflation. In this study, general inflation rate derived from consumer price index will be used.

LNGOVCt: Natural logarithms of government consumption: Assess the importance of direct government expenditures on goods and services. It can be measured by the amount of government consumption.

LNGOVBt: Natural logarithms of government budget balance: The government budget balance, also alternatively referred to as general government balance, public budget balance, or public fiscal balance, is the overall difference between government revenues and spending or simply primary deficit before interest payments. It can be measured with government budget balance during 1994/95 $\mathrm{S}_{1}-2016 / 17 \mathrm{~S}_{2}$.

LNGDIdPt: Natural logarithms of gross domestic investment due to privatization: Gross domestic investment form privatization is measured by the number of privatization proceeds from Ethiopian investors plus significant new investment for replacement purchases, net additions to capital assets to refurbish and modernize existing assets and investments in inventories.

LNFDIdP: Natural Logarithms of foreign direct investment due to privatization: Privatization in developing countries has attracted considerable amounts of attention from foreign investors. These investors can participate in privatization either through foreign direct investment (FDI) or portfolio equity investment. The distinction between the two types of investment depends, in part, on the extent of the investor's own involvement in the privatized company. Generally, portfolio equity investment is a purely financial investment with the foreign investor's share in equity not exceeding 10 percent of the recipient company's total equity capital. FDI, on the other hand, normally involves management control.

In addition, privatized companies often require significant new investment to refurbish and modernize existing assets. In some cases, the government imposes the requirement that purchasers of state-owned assets must pledge additional investment resources at a later date. Hence, FDI form privatization is measured by the number of privatization proceeds from foreign investors plus significant new investment to refurbish and modernize existing assets.

DROUGHT VARIABLE (DDUMMY): recurrent drought and unfavorable weather-conditions have a negative impact on the economy, especially in developing countries that are predominantly dependent on agriculture. Therefore, recurrent drought dummy (ddummy) are added to the model. The drought dummy takes zero if there was relatively good weather-conditions and one if there was a drought. The drought periods are determined based on the findings of (Webb, Braun, and Yisehac, 1992; Viste, Korecha, and Sorteberg, 2012 ).

The level-log form of specification enables the researcher to interpret the coefficient of the dependent variables directly a unit changes with respect to the independent variables (Sarmad, 1988). In addition, it is also useful for accommodating the heteroskedasticity problem (Goldstein and Khan, 1976).

\section{RESULTS AND DISCUSSION}

\subsection{The Unit Root Test Analysis}

In order to determine the degree of integration, a unit root test was carried out using the standard Augmented Dickey-Fuller (ADF) and Phillips-Perron test statistic (PP) test. Moreover, in applying ARDL model, all the variables entered in the regression should not be integrated of order two. To check these conditions, unit root test was conducted before any sort of action taken. Even though the ARDL framework does not require pre-testing variables to be done, the unit root test could convenience us whether or not the ARDL model should be used. The result in Table 1 shows that there is a mixture of $\mathrm{I}(0)$ and $\mathrm{I}(1)$ but not any order two. 
Table-1: Unit Root Test (Augmented Dickey-Fuller Test)

\begin{tabular}{|l|r|r|r|r|r|r|}
\hline \multirow{2}{*}{ Augmented Dickey-Fuller Test statistic (ADF Test) } \\
\cline { 2 - 7 } & \multicolumn{3}{|c|}{ Vith intercept } & \multicolumn{3}{|c|}{ trend and intercept } \\
\hline Aariables & At Level & $\begin{array}{c}\text { Ot First } \\
\text { Difference }\end{array}$ & $\begin{array}{c}\text { Integration and } \\
\text { level of } \\
\text { significant }\end{array}$ & At Level & $\begin{array}{c}\text { Order of } \\
\text { At First } \\
\text { Difference }\end{array}$ & $\begin{array}{c}\text { Integration and } \\
\text { level of } \\
\text { significant }\end{array}$ \\
\hline GRGDP & -2.307 & -5.925 & $\mathrm{I}(1)$ at $1 \%$ & -4.805 & -5.835 & $\mathrm{I}(0)$ at $1 \%$ \\
\hline LNPRIV & -3.801 & -8.088 & $\mathrm{I}(0)$ at $1 \%$ & -7.699 & -7.940 & $\mathrm{I}(0)$ at $1 \%$ \\
\hline INFL & -3.204 & -5.872 & $\mathrm{I}(1)$ at $1 \%$ & -3.614 & -5.935 & $\mathrm{I}(1)$ at $1 \%$ \\
\hline LNGOVC & 1.211 & -4.320 & $\mathrm{I}(1)$ at $1 \%$ & -0.362 & -4.405 & $\mathrm{I}(1)$ at $1 \%$ \\
\hline LNGOVB & -4.026 & -4.543 & $\mathrm{I}(0)$ at $1 \%$ & -2.214 & -4.821 & $\mathrm{I}(1)$ at $1 \%$ \\
\hline LNGDIdP & -3.978 & -6.888 & $\mathrm{I}(0)$ at $1 \%$ & -5.536 & -6.870 & $\mathrm{I}(0)$ at $1 \%$ \\
\hline LNFDIdP & -3.567 & -4.214 & $\mathrm{I}(1)$ at $1 \%$ & -1.707 & -5.165 & $\mathrm{I}(1)$ at $1 \%$ \\
\hline
\end{tabular}

Note: The rejection of the null hypothesis is based on MacKinnon (1996) critical values. Schwarz information criterion (SIC) is used to determine the lag length while testing the stationarity of all variables

Source: Eview 9.5 results

As we have seen from table 1, GRGDP, Inflation (INFL), government consumption (LNGOVC), and foreign direct investment due to privatization (LNFDIdP) are integrated of order 0ne (I.e. I(1)) while privatization (LNPRIV), government budget balance (LNGOVB) and gross domestic investment due to privatization (LNGDIdP) are integrated of order zero (I(0)). Meaning GRGDP, Inflation (INFL), government consumption (LNGOVC), and foreign direct investment due to privatization (LNFDIdP) are stationary in first difference whereas privatization (LNPRIV), government budget balance (LNGOVB) and gross domestic investment due to privatization (LNGDIdP) are stationary in level.

Table-2: Unit Root Test (Phillips-Perron Test Statistic Test)

\section{Phillips-Perron test statistic (PP Test)}

\begin{tabular}{|l|l|l|l|l|l|l|}
\hline \multirow{2}{*}{ Variables } & \multicolumn{3}{|c|}{ with intercept } & \multicolumn{3}{c|}{ trend and intercept } \\
\cline { 2 - 7 } & At Level & $\begin{array}{c}\text { At First } \\
\text { Difference }\end{array}$ & $\begin{array}{c}\text { Order of Integration and } \\
\text { level of significant }\end{array}$ & At Level & $\begin{array}{c}\text { At First } \\
\text { Difference }\end{array}$ & $\begin{array}{c}\text { Order of Integration } \\
\text { and level of significant }\end{array}$ \\
\hline GRGDP & -2.351 & -3.835 & $\mathrm{I}(1)$ at $1 \%$ & -2.442 & -3.718 & $\mathrm{I}(1)$ at $5 \%$ \\
\hline LNPRIV & -6.636 & -19.264 & $\mathrm{I}(0)$ at $1 \%$ & -7.508 & -18.399 & $\mathrm{I}(0)$ at $1 \%$ \\
\hline INFL & -2.261 & -6.085 & $\mathrm{I}(1)$ at $1 \%$ & -2.388 & -6.137 & $\mathrm{I}(1)$ at $1 \%$ \\
\hline LNGOVC & -0.702 & -4.363 & $\mathrm{I}(1)$ at $1 \%$ & -1.076 & -4.453 & $\mathrm{I}(1)$ at $1 \%$ \\
\hline LNGOVB & -2.219 & -6.373 & $\mathrm{I}(1)$ at $1 \%$ & -1.930 & -6.596 & $\mathrm{I}(1)$ at $1 \%$ \\
\hline LNGDIdP & -4.048 & -15.206 & $\mathrm{I}(0)$ at $1 \%$ & -4.186 & -14.871 & $\mathrm{I}(0)$ at $1 \%$ \\
\hline LNFDIdP & -3.567 & -3.833 & $\mathrm{I}(1)$ at $1 \%$ & -1.784 & -4.510 & $\mathrm{I}(1)$ at $1 \%$ \\
\hline
\end{tabular}

Note: The rejection of the null hypothesis is based on MacKinnon (1996) critical values. Schwarz information criterion (SIC) is used to determine the lag length while testing the stationarity of all variables

Source: Eview 9.5 results

Similarly, the PP test shows that there is a mixture of integration order zero and order one. That is, GRGDP, inflation(INFL), government consumption (LNGOVC), government budget (LNGOVB) and foreign direct investment due to privatization(LNFDIdP) are stationary in first difference while privatization (LNPRIV) and gross domestic investment due to privatization (LNGDIdP) are stationary in level. Form table 1 and 2 we can conclude that none of the variables entered in the regression are order two, which are not desired in applying ARDL model. So ARDL co-integration technique proposed by Pesaran et al. (2001) is the most appropriate method for estimation or to check the long run relationship among the variables. So ARDL co-integration technique proposed by Pesaran et al. (2001) is the most appropriate method for estimation or to check the long run relationship among the variables.

\subsection{Model Stability and Diagnostic Test}

To check the verifiability of the estimated long-run model, some diagnostic test is undertaken. Priority in doing any analysis, we required checking the standard property of the model. In this study, we carried a number of model stability and diagnostic checking, which includes Serial correlation test (Brush \& Godfray LM test), Functional form (Ramsey's RESET) test, Normality (Jaque-Bera test), and Heteroscedasticity test. In addition to the above diagnostic tests, the stability of long-run estimates has been tested by applying the cumulative sum of recursive residuals (CUSUM) and the cumulative sum of squares of recursive residuals (CUSUMSQ) test. Such tests are recommended by Pesaran et al. (2001). In order to reject or accept the null hypothesis, we can decide by looking the p-values associated with the test statistics. That is the null hypothesis is rejected when the p-value is 
smaller than the standard significance level (I.e. 5\%).

Table -3: Diagnostic Test for the Long Run ARDL $(4,1,3,2,3,1,3)$

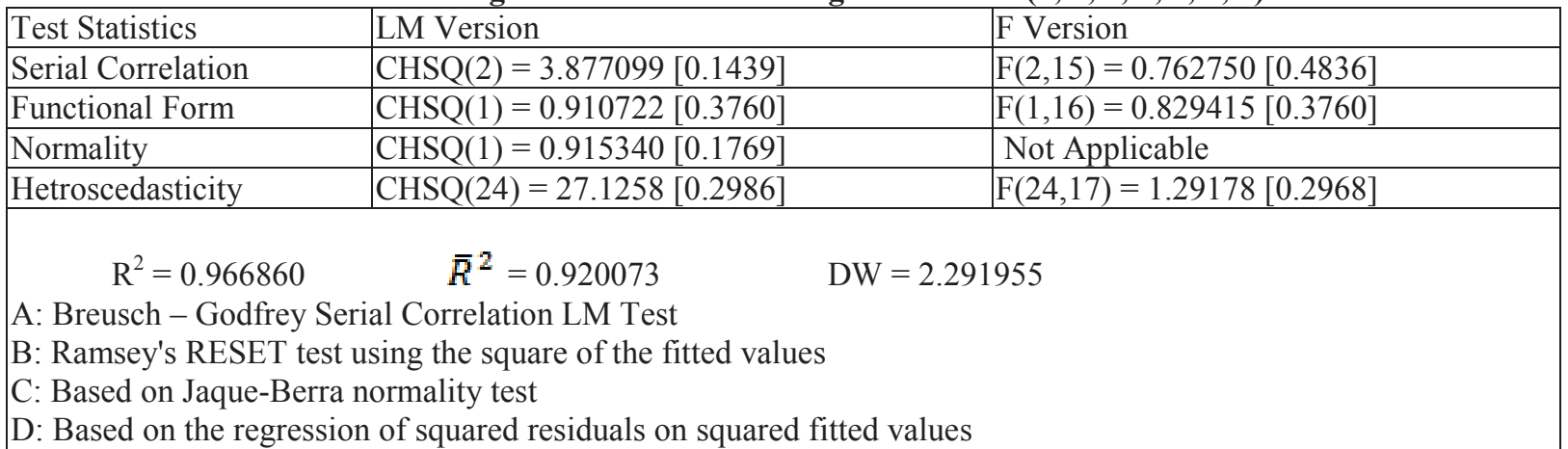

\section{Source: Eview 9.5 results}

The above table indicates that the long run ARDL model estimated in this study passes all the diagnostic tests. This is because the p-value associated with both the LM version and the F version of the statistic was unable to reject the null hypothesis specified for each test. Therefore based on the result of the test:

(A) The null hypothesis of no serial correlation (Breusch - Godfrey Serial Correlation LM Test) is failed to reject for the reason that the $\mathrm{p}$-values associated with test statistic are greater than the standard significant level (I.e. $0.1439>0.05$ ). Her LM test for testing serial correlation is applied because unlike the traditional Durbin Watson test statistic which is totally inapplicable when the lagged dependent variable appears as regressors, LM test avoid such limitation of DW test.

(B) We could not reject the null hypothesis test for Ramsey's RESET test, which tests whether the model suffers from omitted variable bias or not. As the test result indicates that we can't reject Ramsey's test, which means that the model is correctly specified. (I.e $0.3760>0.05$ )

(C) The third diagnostic test is about the residual test. As the result indicates that we could not reject the null hypothesis which says that the residuals are normally distributed, for the reason, that the $\mathrm{p}$-value associated with the Jaque-Berra normality test is larger than the standard significance level (I.e. $0.1769>0.05$ ).

(D) The last diagnostic test is for heteroscedasticity test. As we have seen from the above table, we can reject at $5 \%$ significant level due to its p-value associated with the test statistics are greater than the standard significance level( I.e. $0.2986>0.05$ ).

Moreover, the stability of the model for the long run and short run relationship is detected by using the cumulative sum of recursive residuals (CUSUM) and the cumulative sum of squares of recursive residuals (CUSUMSQ) tests. The test finds serious parameter instability if the cumulative sum goes outside the area (never returns back) between the two critical lines.

Figure 1: Testing Parameter Stability Using CUSUM and CUSUMSQ Test - Plot of Cumulative Sum of Recursive (A)

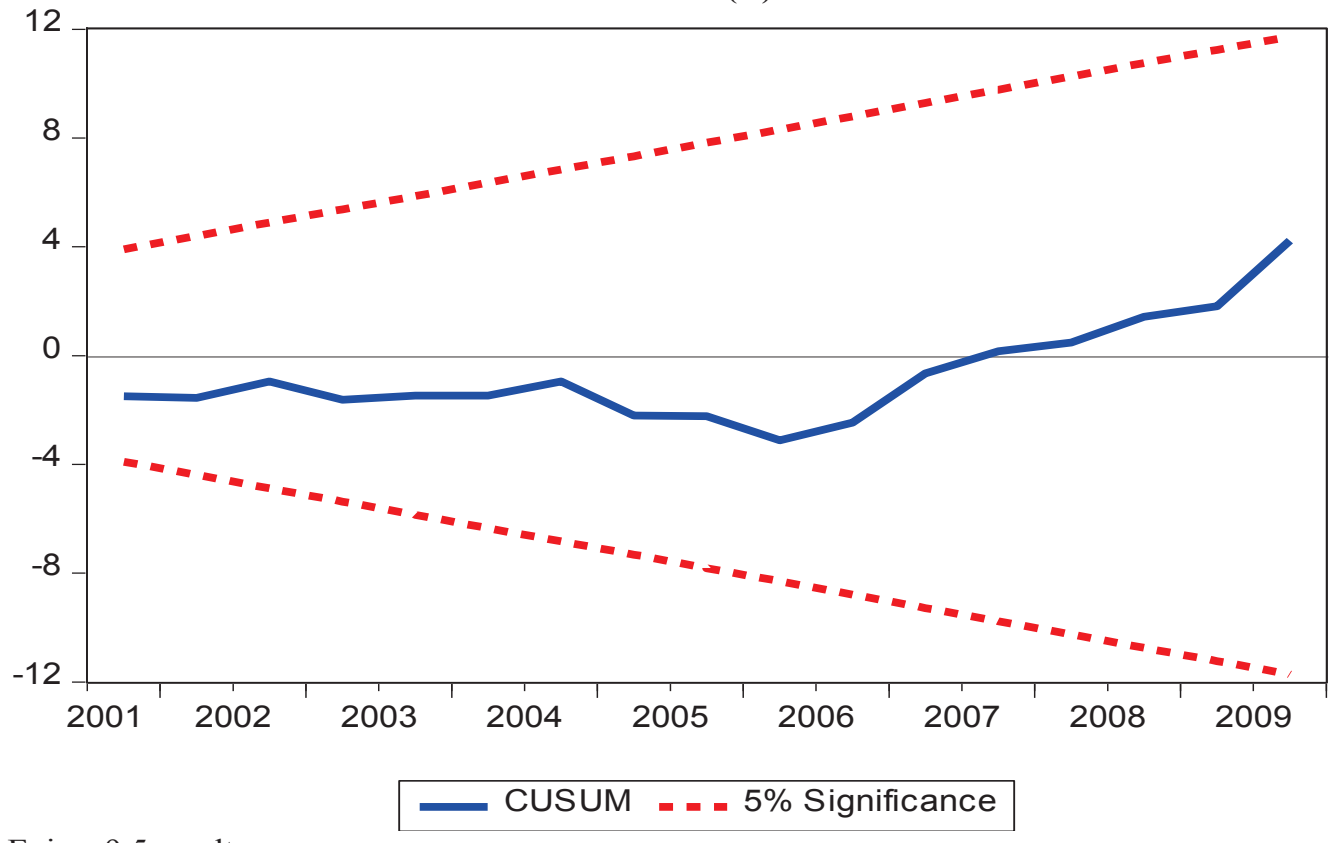

Source: Eview 9.5 results 
Figure 2: Testing Parameter Stability Using CUSUM and CUSUMSQ Test - Plot of Cumulative Sum of Recursive (B)

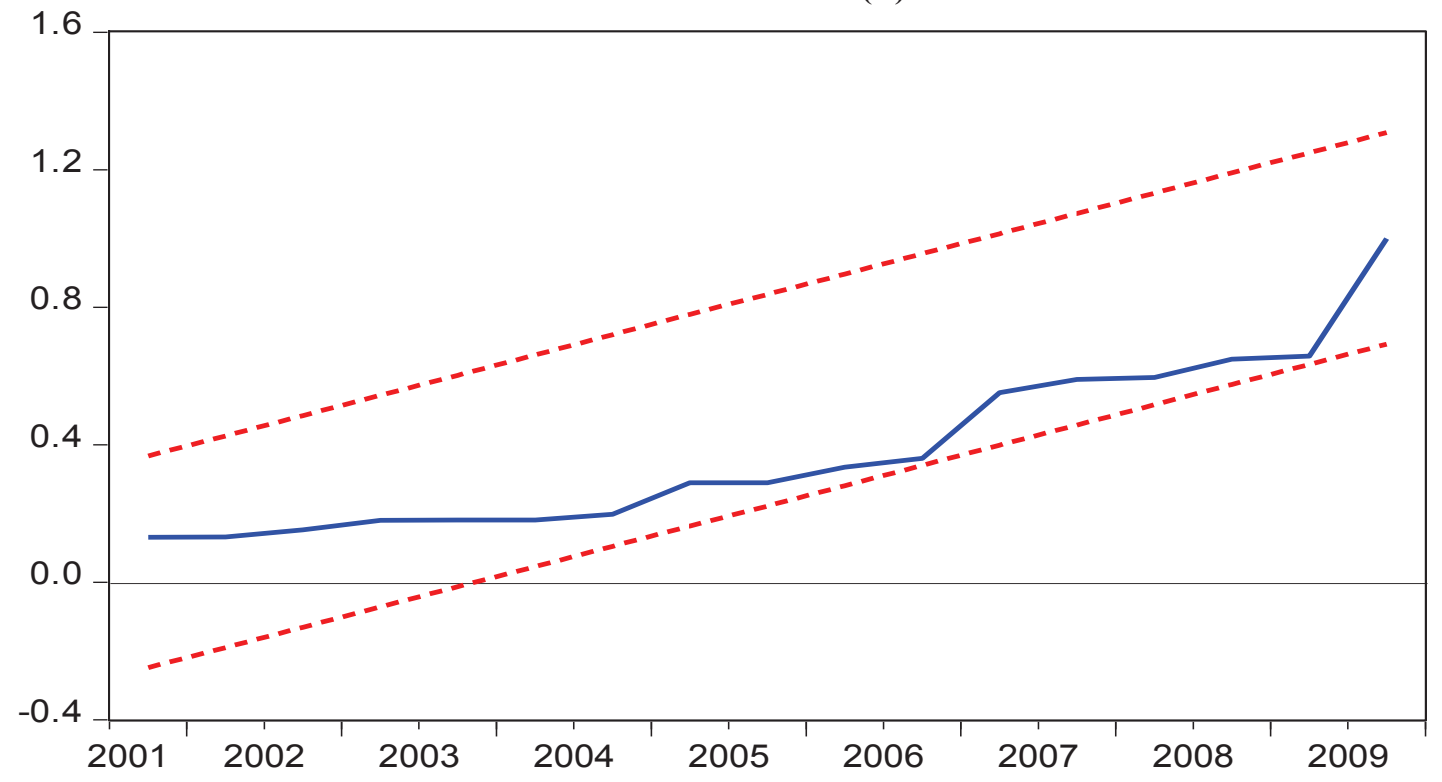

Source: Eview 9.5 results

$$
\text { _ CUSUM of Squares --- } 5 \% \text { Significance }
$$

The straight lines represent critical bounds at 5\% significance level.

As can be seen from the first figure (1- A), the plot of CUSUM test did not cross the critical limits. Similarly, the CUSUMSQ (figure 1- B), the test shows that the graphs do not cross the lower and upper critical limit. So, we can conclude that long-run estimates are stable and there is no any structural break. In addition to the model stability, $92 \%$ of the model has been explained by the regressors. Hence the results of the estimated model are reliable and efficient.

\subsection{Long Run ARDL Bounds Tests for Co-integration}

This part of the study answers the hypothesis stated in the research hypothesis number one of chapter one which says:

Ho (Null Hypothesis): there is no long run co-integration between privatization and economic growth.

Ha (Alt. Hypothesis): there is long run co-integration between privatization and economic growth.

Since I determined the stationary nature of the variables, the next task in the bounds test approach of cointegration is estimating the ARDL model specified in equation (4) using the appropriate lag-length selection criterion. A lag length that minimizes AIC is 5. In addition to this, we have also used AIC to determine the optimal lag because it is a better choice for smaller sample size data as this study. Apart from this, AIC found to produce the least probability of underestimation among all criteria available (Liew et al., 2004) as cited in Tsadkan (2013).

As we discuss in the third part of this study, the F-test through the Wald-test (bound test) is performed to check the joint significance of the coefficients specified in equation (4). The Wald test is conducted by without imposing restrictions on the estimated long-run coefficients of real growth domestic product (GRGDP) , Privatization (LNPRIV), Inflation (INFL), government consumption (LNGOVC), government budget ( LNGOVB), gross domestic investment due to privatization ( LNGDIdP) and foreign direct investment due to privatization (LNFDIdP). The computed F-statistic value is compared with the lower bound and upper bound critical values provided by Pesaran et al. (2001) and Narayan (2004).

Table -4: Calculated F-Statistic

\begin{tabular}{|l|l|l|}
\hline Number of observation & Lag Length & Value of Calculated F-Statistic \\
\hline 46 & 5 & $9.706962[0.0001]$ \\
\hline
\end{tabular}

Source: Eviews 9.5 result

As we have seen from the above table the calculated F-statistic is strongly significant at 1 percent significance level. 
Table-5: The Upper and Lower Critical Values

\begin{tabular}{|l|l|l|l|l|}
\hline \multirow{4}{*}{$\begin{array}{l}\text { Critical } \\
\text { Values }\end{array}$} & \multicolumn{3}{|l|}{ Pesaran et al. (2001) } & Narayan (2004) \\
\cline { 2 - 5 } & Lower Bound Value & $\begin{array}{l}\text { Upper Bound Value } \\
\mathrm{I}(0)\end{array}$ & $\begin{array}{l}\text { Lower Bound Value } \\
\mathrm{I}(0)\end{array}$ & $\begin{array}{l}\text { Upper Bound Value } \\
\mathrm{I}(1)\end{array}$ \\
\hline $1 \%$ & 3.15 & 4.43 & 3.790 & 5.411 \\
\hline $5 \%$ & 2.45 & 3.61 & 2.764 & 4.123 \\
\hline $10 \%$ & 2.12 & 3.23 & 2.327 & 3.541 \\
\hline
\end{tabular}

Source: Pesaran, Shin, and Smith (2001) and Narayan (2005) tables and Eviews 9.5 result

The critical values reported for Pesaran et al. (2001) are the case with unrestricted intercept and no trend (CI (iii) case III). In this study, I have been used Narayan (2004) which is developed based on 30 to 80 observations. As it is depicted in Table 4 and 5 above, with an intercept and no trend, the calculated F statistics (9.706962) is higher than both the Pesaran et al. (2001) and Narayan (2004) upper bound critical values at 1\% level of significance. This implies that the null hypothesis of no long-run relationship is rejected; rather accept the alternative hypothesis (there is a long-run relationship) based on the Pesaran et al. (2001) and Narayan (2004) critical values at $1 \%$ level of significance. Therefore, there is a co-integration relationship between the variables in long run.

\subsection{Long Run ARDL Model Estimation}

After confirming the existence of a long-run co-integration relationship among the variables, the next step is running the appropriate ARDL model to find out the long run coefficients, which is reported in table 4.6 below.

Table-6: Estimated Long Run Coefficients Using The ARDL Approach ARDL $\quad(4,1,3,2,3,1,3)$ Selected Based on Akaike Information Criterion.

\begin{tabular}{|l|l|l|l|}
\hline \multicolumn{5}{|l|}{ Dependent Variable is GRGDP } \\
\hline Regressors & Coefficient & Standard Error & T-Ratio[prob] \\
\hline LNPRVI & 0.460307 & 0.151335 & $3.041652[0.0074]^{*}$ \\
\hline INFL & -0.012199 & 0.054728 & $-0.222901[0.8263]$ \\
\hline LNGOVC & -0.540224 & 0.559621 & $-0.965339[0.3479]$ \\
\hline LNGOVB & -0.153357 & 0.068275 & $-2.246153[0.0383]^{* *}$ \\
\hline LNGDIdP & -0.707116 & 0.500593 & $-1.412558[0.1758]$ \\
\hline LNFDIdP & 1.577176 & 0.657822 & $2.397573[0.0283]^{* *}$ \\
\hline DDUMMY & -0.795133 & 0.538286 & $-1.477157[0.1579]$ \\
\hline C & -16.05066 & 17.60281 & $-0.9118286[0.3746]$ \\
\hline & \multicolumn{3}{|l}{} \\
\hline
\end{tabular}

Source: Author's Calculations.

Note: The $* * *$ and $* * *$ sign indicate the significance of the coefficients at $1 \%, 5 \%$ and $10 \%$ significant level respectively.

As the long run estimated result of the above table showed, the privatization which is proxied by the amount of proceeding has a positive impact on Ethiopian economic growth and statistically significant at $1 \%$ significance level.

This result is in-line with the main assumption of privatization theories is that the free forces of market increase the efficiency of a firm. (Property rights theory, Principal-agent theory, and Public choice theory). Moreover, this study's result is consistent with the study of Zinnes et al (2001), Barnett et al (2004). Gupta (2005), Filipovic (2008) and Shahraki et al (2011).

Since I have specified the growth model in a level-log regression, the coefficients can be interpreted as a unit change with respect to real GDP which is the proxy of economic growth. The coefficient of privatization (LNPRVI) is 0.460307 . This indicates that, in the long run, holding other things constant, a one percent change in privatization proceed brought 0.00460307 unit(birr) change in real GDP during the study period.

The general inflation rate, as shown in the above table 6 has a negative impact on Ethiopian economic growth, even though statistically insignificant. In the Ethiopian history, inflation remained at a reasonable lowlevel rate until 2002/03. But after 2004, the inflation rate increased and reached 36.4 percent in 2000 (NBE, 2014/15), which was caused primarily by food inflation and affect the well-being of the society than harming the macroeconomic performance. The insignificant effects of inflation on Ethiopian economic growth might be associated with the reasonable low level (single digit) inflation rate until 2003 as we discussed in chapter four of this study. Moreover, the result of this study also consistent with (Khan and Senhadji, 2000) and Bawa and Abdullahi (2010) as an average inflation registered 9.7 percent during the study period. From the descriptive and econometric result, we can understand that inflation does not harm the economic growth significantly for the study period.

Next, to inflation, government consumption is not statistically significant at $1 \%, 5 \% \& 10 \%$ significance 
level in the study period. Perhaps the most interesting result pertaining to the control variables is the negative coefficient of the variable LnGOVC, representing the negative effect of level of government spending. The theoretical reason for including LNGOVC as a control variable was based on the idea that it would be a proxy for government corruption, and therefore should have a negative coefficient. Thus, a negative coefficient is not contrary to theory and somewhat interesting. The findings of this research concerning the long run negative impact of the GOVC on Ethiopian economic growth, are consistent in previous analyses (Barro, 1989,1990) he found that the ratio of real government consumption expenditure to real GDP had a negative association with growth and investment. The argument was that government consumption had no direct effect on private productivity (or private property rights), but lowered saving and growth through the distorting effects of taxation or government-expenditure programs. Most of government- expenditure programs are suitable for corruption.

The result of this study revealed that the impact of government budget balance on Ethiopian economic growth is significantly high during the study period, even if there is a negative relationship, which is not expected. This significant result might be associated with the primary deficit(as we discussed in part three of this study, more than 90 percent of government budget balance is negative) in the study period, which suffered from budget shortage and this shortage financed by privatization proceeds. As we discussed in chapter three is a tendency that the Ethiopian government privatizing SOEs in order to create revenues to pay for the deficit rather than making privatization decisions based on the goals of economic growth.

The other reason behind negative result of LNGOVB might be associated with huge gap resource balance, which indicates that budget balance has a significant impact on Ethiopian economic growth. This result also confirmed by MoFED particularly during 2011/12 and 2012/13 despite it was expected to play an important role in accelerating the economic growth during the GTP period.

The hypothesis related to foreign direct investment in the research hypothesis number two of chapter one for the long run relationship between foreign direct investment due to privatization (FDIdP) and economic growth was analyzed below

Ho (Null Hypothesis): Foreign Direct Investment (FDI) due to privatization has no effect on economic growth. Ha (Alternative Hypothesis): Foreign Direct Investment (FDI) due to privatization has an effect on economic growth.

The foreign direct investment due to privatization, which is measured by total foreign direct investment (foreign privatization proceed and additional investment to refurbishes their old asset) is positive and statistically significant at 5 percent significance level. This result indicates that the existing foreign direct investment due to privatization in the country during the study periods has a significant effect on Ethiopian economy. This implies that the null hypothesis of foreign direct investment (FDI) due to privatization has no effect on economic growth was rejected and the alternative hypothesis was accepted. As the result, a one percent increase in the foreign direct investment due to privatization will result in 0.01577176 unit (birr) increase in real GDP.

The hypothesis related to private domestic investment in the research hypothesis number three of chapter one for the long run relationship between private domestic investment due to privatization (GDIdP) and economic growth was analyzed below

Ho (Null Hypothesis): Private Domestic investment due to privatization (GDIdP) has no effect on economic growth.

Ha (Alternative Hypothesis): Private Domestic investment due to privatization (GDIdP) has an effect on economic growth.

In table 6 the coefficient of LNGDIDP is insignificant, Implies that I failed to reject null hypothesis private domestic investment due to privatization has no effect on economic growth.

The unexpected negative coefficient of LNGDIDP along with the fact that it is statistically insignificant, This insignificant and negative result might be associated with Domestic investment in Ethiopia increased in absolute terms starting from 1994/95 up to 2008/09 and starts to decline from the year 2008/09 up to now. The inflow of foreign investment as a crowding out effect will be the main reason for the negative result. During the ten years period from 1994/95- 2003/04 the investment of domestic had dormant to a large extent. Moreover, this result because of law saving and capital the availability of domestic private investment due to privatization is law. This fact undoubtedly creates a fear that privatization would necessarily result in 'foreignization' which is not desirable for Ethiopian economic growth.

Liberalization of trade in 1992 made an impact on the country domestic investment growth (Economic Commission for Africa, P83, (2002)). The reform, as well as the government introduction of investment guarantee scheme and incentives, helped the county to get/get a lower level of domestic investment form 19942003. The domestic investment to Ethiopia has been generally trending upward, along with some volatility, since 2003/04. Moreover, the investment proclamation was revised by including a higher level of incentives for foreign investors lower and adversely affects the domestic investment.

The long run, the drought dummy variable as (DDUMMY)) have a negative impact on Ethiopian economic growth and statistically insignificant in the study period. 
Finally, the long run estimated model presented as follow with figures in the parenthesis indicates calculated t-value.

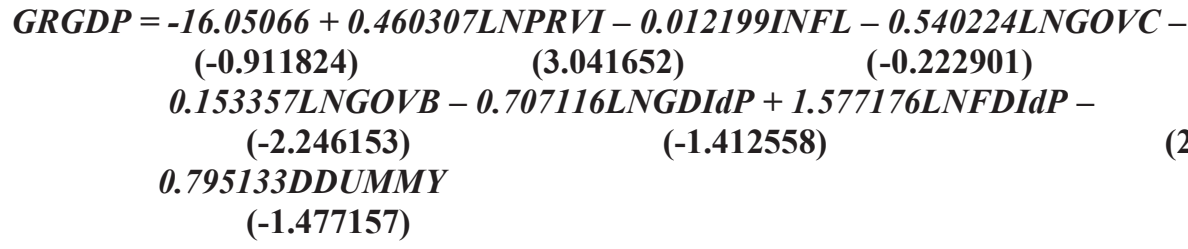

\subsection{Short Run Error Correction Model}

After the acceptance of long-run coefficients of the growth equation, the short-run ECM model is estimated. The error correction term (ECM), as we discussed in chapter three, indicates the speed of adjustment to restore equilibrium in the dynamic model. It is a one lagged period residual obtained from the estimated dynamic longrun model. The coefficient of the error correction term indicates how quickly variables converge to equilibrium. Moreover, it should have a negative sign and statistically significant at a standard significant level (i.e. p-value should be less than 0.05 ).

Table -7: Error Correction Representation for the Selected ARDL (4, 1, 3, 2, 3, 1, 3) Selected Based on Akaike Information Criterion

\section{Dependent Variable is D(GRGDP)}

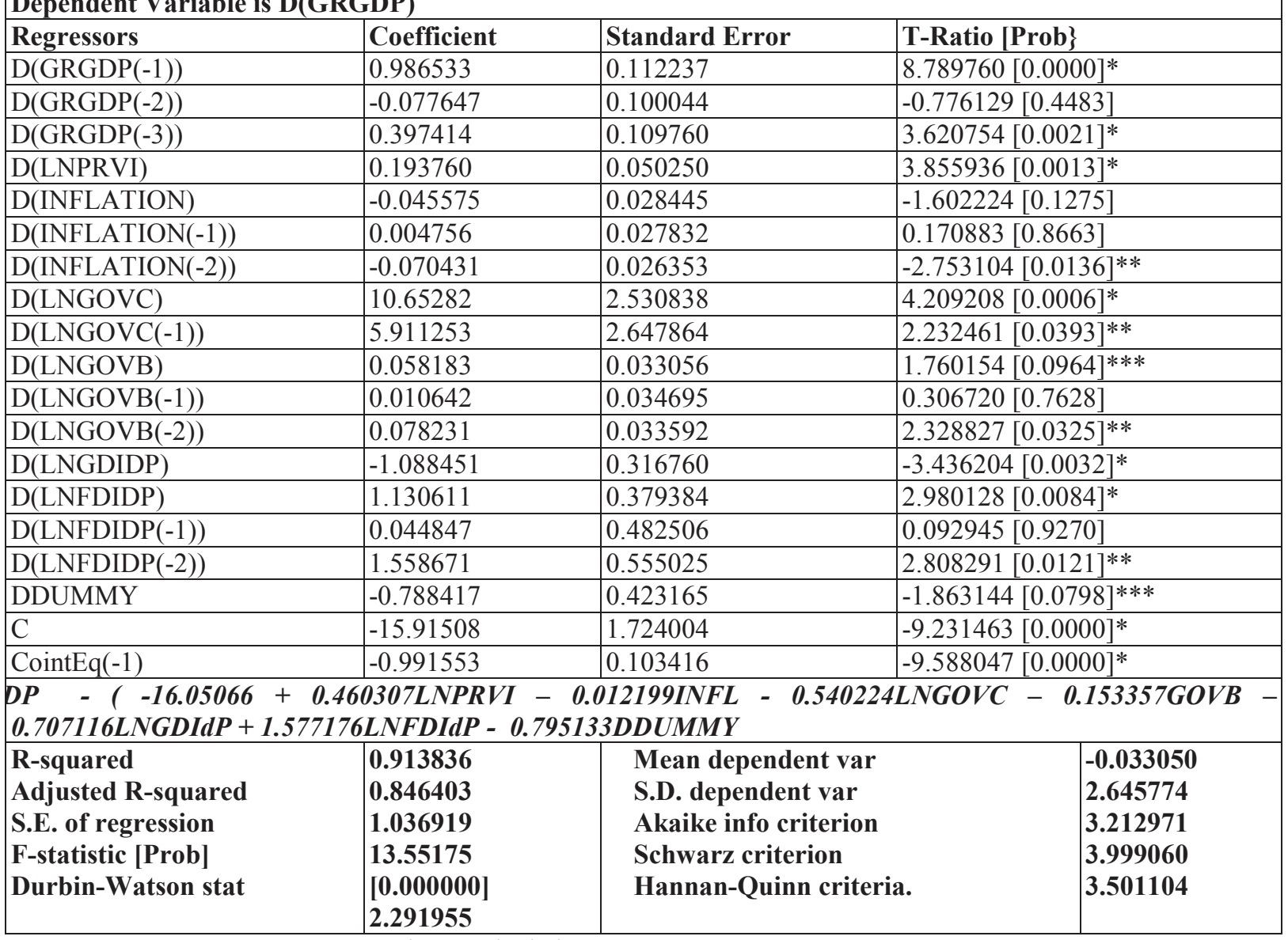

Source: Eviews 9.5 result and author's calculations.

Note: The $* * *$ and $* * *$ sign indicate the significance of the coefficients at $1 \%, 5 \%$ and $10 \%$ significant level respectively.

The error correction coefficient, estimated at -0.991553 is highly significant, has the correct negative sign, and imply a very high speed of adjustment to equilibrium. According to Bannerjee et al. (2003), as cited in Kidanemarim (2014), the highly significant error correction term further confirms the existence of a stable shortrun relationship.

Moreover, the coefficient of the error term (ECM (-1)) implies that the deviation from long-run equilibrium level of real GDP in the current period is corrected by $99.16 \%$ in the next period to bring back equilibrium when there is a shock to a steady state relationship.

The coefficient of determination (R-squared) is high explaining that about $84.7 \%$ of the variation in the real 
GDP is attributed to variations in the explanatory variables in the model. In addition, the DW statistic does not suggest autocorrelation and the F-statistic is quite robust.

As Chandran et al. (2010), which is quoted in Tsadkan (2013), the long run effect of the model can be captured by the error term (ECM). Thus, in the long run, LNPRVI, INFLATION, LNGOVC, INGOVB, LNGDIdP and LNFDIdP granger cause GRGDP (i.e. unidirectional causality). Not only this but also in applying autoregressive distributed lag (ARDL) model, does not require testing for Granger causality since, it considers an endogeneity problem in the model (Wessene, 2014).

From the above table 7, similar to the long run result, privatization (LNPRVI) have a positive impact on Ethiopian economic growth and statistically significant at 1 percent significance level, respectively in the short term. As a result, a one percent increases in privatization proceeds will result in 0.0193760 birr increases in real GDP in the short run.

On the other hand, inflation of goods and service is still insignificant like the long run, with a negative coefficient, which indicates it is not contrary to economic theory, the negative relationship between inflation and Ethiopian economic growth. However, with two periods lagged, inflation is significant at 5 percent significance level with negative coefficient in the short term. Which mean one percent change in inflation of goods and service will result in a decrease in real GDP by 0.00072552 birrs in two lagged periods.

Unlike the long run, the LNGOVC and one period lagged, the variable is significant affects economic growth in the short run at 1 and 5 percent level. But, the sign is positive which is not expected because I including LNGOVC as a control variable was based on the idea that it would be a proxy for government corruption, and therefore should have a negative coefficient. Moreover, this result is not consistent with Barro $(1989,1990)$ found that the ratio of government consumption to GDP had a negative association with growth.

Unlike to the long run effect, the government budget deficit (LNGOVB) variable is found to have a positive relationship with real GDP and significant a $10 \% \& 5 \%$ in the level and second lag. It implies that privatization proceeds were used to finance the government budget deficit in the short run. However, at one semi-annual lags result indicates that government budget balance has a positive sign and not significant. The result at two semiannual lag is significant at 5 percent significance level. As a result, a one percent increase in government budget due to privatization will result in an increase in the real GDP by 0.00078231 birr in short run. At level government budget balance is significant at $10 \%$ level. As a result, a one percent increase in government budget due to privatization will result in an increase in the real GDP by 0.00058183

The hypothesis related to foreign direct investment in the research hypothesis number two of chapter one for the short run relationship between foreign direct investment due to privatization (FDIdP) and economic growth was analyzed below

Ho (Null Hypothesis): Foreign Direct investment due to privatization (FDIdP) has no long run or short run effect on economic growth.

Ha (Alternative Hypothesis): Foreign Direct investment due to privatization (FDIdP) has no long run or short run effect on economic growth.

As one can understand from the above table 7, foreign direct investment due to privatization (LNFDIdP) is highly significantly affecting Ethiopian economic growth during the study period, despite their relationship is positive in short run. This implies the null hypothesis foreign direct investment due to privatization (FDIdP) has no long run or short effect on economic growth was rejected. From this, we can understand that during the study period, in the short run, foreign direct investment due to privatization does have a significant positive impact on the Ethiopian economic growth. The result is significant at 1 percent significance level. As a result, a one percent increase in foreign direct investment as a result of privatization will result in an increase in the real GDP by 0.01130611 birrs in short run. However, at one semi-annual lags result indicates that foreign direct investment has a positive sign and not significant and two semi-annual lags result indicates the government budget balance have a positive sign and statically significant at 5\% level of significance. As a result, a one percent increase in government budget as a result of privatization will result in an increase in the real GDP by 0.01558671 birrs in short run.

The hypothesis related to private domestic investment in the research hypothesis number three of chapter one for the short run relationship between private domestic investment due to privatization (GDIdP) and economic growth was analyzed below

Ho (Null Hypothesis): Private Domestic investment due to privatization (GDIdP) has no long run and short run effect on economic growth.

Ha (Alternative Hypothesis): Private Domestic investment due to privatization (GDIdP) has long run and short run effect on economic growth.

In table 4.7 the coefficient of LNGDIDP is significant, Implies that the null hypothesis of private domestic investment due to privatization has no long run and short run effect on economic growth was rejected.

Similar to the long run effect, the gross domestic investment due to privatization (LNGDIDP) variable is found to have a negative relationship with real GDP, which is not expected. But it is significant at $1 \%$ in the 
level.

Unlike to the long run result, the drought dummy variable as (DDUMMY)) have a negative impact on Ethiopian economic growth and statistically significant at 10 percent significance level, respectively in the short term. As a result, when there are droughts 0.788417 birr decreases in real GDP will occur in the short run. This result is consistent with the finding of Kidanemariam(2014).

\section{CONCLUSION AND POLICY RECOMMENDATION}

\subsection{Conclusion}

The main objective of this study is to analyze the impact privatization on economic growth in Ethiopia during the specified period. To determine the long run and the short run relationship between the variables, Autoregressive Distributed Lag (ARDL) model was applied. Before applying the ARDL model, all the variables are tested for their time series properties (stationarity properties) using the ADF and PP tests. As a result, GRGDP, inflation(INFL), government consumption (LNGOVC) and foreign direct investment due to privatization (LNFDIdP) are stationary in first difference while privatization (LNPRIV), government budget (LNGOVB) and gross domestic investment due to privatization (LNGDIdP) are stationary in level.

Next, to testing for time series property, the model stability was done by testing the diagonal testing techniques. The result revealed that no evidence of serial correlation, no functional form problem (the model is correctly specified), the residual is normally distributed and no evidence of heteroscedasticity problem. As we discussed above, this study applied the methodological approach called ARDL model also known as bound test approach. As the result indicted the bound test (F-statistic) value is larger than the upper bound critical value both for Pesaran et al. (2001) and Narayan (2004), which indicates there is a long run relationship between real GDP and its determinants in long run during the study period.

The empirical result showed that privatization (LNPRIV) \& foreign direct investment due to privatization (LNFDIDP) are found to have a positive impact on Ethiopian economic growth during the study period and statistically significant at $1 \& 5$ percent significance level respectively. A one percent increase in privatization proceeds results in 0.00460307 and 0.00193760 birr increase in real GDP in the long run and short run, respectively. Likewise, a one percent increase in foreign direct investment will result in 0.01577176 and 0.01130611 birr increase in real GDP in the long run and short run, respectively. The government budget balance also has a negative and significant impact on economic growth during the study period in the long run and positive impact and significant impact in level \& two semi-annual lag periods in the short run. A one percent increase in government budget balance in two semi-annual lag periods will result in 0.0007823 birr increase in real GDP in the short run. However, the study found out that general inflation has a statistically insignificant impact on economic growth with a negative sign in the long run and statistically significant and negative sign in two semi-annual lag periods in the short run. Implies a one percent increase in general inflation in two semiannual lag period will result in a 0.00072552 unit (birr) decreases in real GDP.

Moreover, this study is found out that privatization proceeds and real domestic growth which are a proxy for economic growth during EPRDF (1994/95-2016/17) has a long run and short run relationship. In the short run, the coefficient of the error correction term is -0.991553 suggesting about 99.16 percent semi-annual adjustment towards long-run equilibrium. This is another proof for the existence of a stable, long-run relationship among the variables. The estimated short-run model reveals that foreign direct investment due to privatization is the main contributor to real GDP change followed by privatization proceed, government budget deficit( tow period lagged value) and inflation (tow period lagged value). In addition to this, the drought dummy is another contributor to GDP in the short run.

\subsection{Policy Recommendation}

Based on the finding of this study, the following policy recommendations are forwarded.

$>$ Privatization policy has a significant positive impact on Ethiopian economic growth. Therefore, the Federal Government of Ethiopia should strengthen the existing privatization policies and modalities of privatization in development and promote investment, particularly in the manufacturing sector. Moreover, the researcher recommends that, as the finding implies, it is possible that some of the success of privatization as a policy that promotes economic growth lies in the fact that privatization leads to other structural changes in the economy, so privatization should be strengthened with other policies.

$>$ In order to enhance the contribution of the foreign direct investment, the government of Ethiopia has to strengthen privatization policies to increase FDI which is believed as a backbone of growth. This includes increase capability of advanced technology, increased access to foreign savings; create competitive advantage and accesses to the international market.

$>$ In order to enhance the contribution of the gross domestic capital formation, the government of Ethiopia has to allocate adequate finance in the form of borrowing and/or different modality of privatization which enables the local people to participate in privatization process in order to cop up with foreigners 
investors.

$>$ As government consumption affects the economic growth of Ethiopia negatively because of corruption, there should be close monitoring and consistent government consumption management strategies, which is used to avoid misallocation and mismanagement of resources. In addition, allocating resources on selected useful goods and services, which used to return back the utilized resources and together with basic infrastructure construction that facilities productive goods and services is decisive.

$>$ Though inflation is not that much a significant problem in Ethiopian growth in the study period it has a negative sign. The federal government should work to reduce the inflation rate if possible, otherwise, it should sustain the existing inflation rate (with a single digit) by tight fiscal and monetary policies, financing of budget deficit from non-inflationary sources and implementation of price stabilization program by subsiding basic food items.

\section{REFERENCES}

Barro, R.J., 1991. Economic growth in a cross section of countries. The quarterly journal of economics, 106(2), pp.407-443.

Bawa Sani and S. Abdullahi Ismaila (2010), "Threshold Effect of Inflation on Economic Growth in Nigeria”, CBN Journal of Applied Statistics Vol. 3 No.1

Bennett, J., Estrin, S., Maw, J. and Urga, G., 2004. Privatization methods and economic growth in transition economies.

Cook, P. and Uchida, Y., 2003. Privatization and economic growth in developing countries. The Journal of Development Studies, 39(6), pp.121-154.

Debebe, F., 2000. Privatization in Sub-Saharan Africa: Origins. Trends, and Influences on Development Strategies, Center For Economic Research on Africa, Montclair, New Jersey.

Economic Commission for Africa, 2002: Economic Report on Africa, 2002: United Nation, pp. 83.

Filipovic, A., 2006. Impact of privatization on economic growth. Undergraduate Economic Review, 2(1), p.7.

Goldsteine, M., and M. Khan (1976). Large versus Small Price Changes and the Demand for Imports. International Monetary Fund, 23(1): 200-225.

Gupta, N., 2005. Partial privatization and firm performance. The Journal of Finance, 60(2), pp.987-1015.

Javad . S., Mosayeb .P. \& Kamran.B.,2011. The Investigation of Relationship between Privatization and Economic Growth in Iran: International Journal of Business, Humanities and Technology Vol. 1 No. 2.

Khan, Mohsin S., and Abdelhak S. Senhadji, (2000), "Threshold Effects in the Relationship Between Inflation and Growth", IMF staff Paper Vol.48, , No.1, June, 2000.

Kidanemariam G. (2014), "The Impact of Human Capital Development on Economic Growth in Ethiopia: Evidence from ARDL Approach to Co-Integration", A Peer-Reviewed Indexed International Journal of Humanities \& Social Science, Vol-II, Issue-IV, April-2014.

Liew V. and Khimsen A. (2004), "Which lag length selection criteria should we employ", Economic Bulletin Vol.3, No.33 pp. 1-9

Narayan K. (2004)," Reformulating Critical Values for the Bounds F-statistics Approach to Cointegration: An Application to the Tourism Demand Model for Fiji”, Discussion Papers No 02, Monash University, Victoria, Australia.

Ogbonna, G.N. and Ebimobowei, A., 2012. Impact of tax reforms and economic growth of Nigeria: A time series analysis. Current Research Journal of Social Sciences, 4(1), pp.62-68.

Pesaran, M.H. and Shin, Y., 1998. An autoregressive distributed-lag modelling approach to cointegration analysis. Econometric Society Monographs, 31, pp.371-413.

Pesaran, M.H., Shin, Y. and Smith, R.J., 2001. Bounds testing approaches to the analysis of level relationships. Journal of applied econometrics, 16(3), pp.289-326.

Plane, P., 1997. Privatization and economic growth: an empirical investigation from a sample of developing market economies. Applied Economics, 29(2), pp.161-178.

Sarmad, K.(1988). The Functional Form of the Aggregate Import Demand Equation: Evidence from Developing Countries. The Pakistan Development Review, 27(3): 309-315.

Shahraki, J., Pahlavani, M. and Barghandan, K., 2011. The investigation of relationship between privatization and economic growth in Iran. International Journal of Business, Humanities and Technology, 1(2), pp.167174.

Tsadkan A. (2013), "The nexus between public spending and economic growth in Ethiopia: Empirical investigation", unpublished Master thesis, Addis Ababa University.

Zinnes, C., Eilat, Y. and Sachs, J., 2001. The gains from privatization in transition economies: is "change of ownership" enough?. IMF Staff papers, 48(1), pp.146-170. 